\title{
TERRORISM ON TRIAL: THE PRESIDENT'S CONSTITUTIONAL AUTHORITY TO ORDER THE PROSECUTION OF SUSPECTED TERRORISTS BY MILITARY COMMISSION
}

\author{
CHRISTOPHER M. EVANS
}

\section{INTRODUCTION}

On November 13, 2001, President George W. Bush, in his capacity as commander in chief, promulgated a Military Order authorizing the trial of noncitizens suspected of complicity in the brutal attacks on September 11, 2001, before specially convened military commissions. ${ }^{1}$ The Military Order of November 13 establishes that, unlike trials in federal district courts, judicial review of the commission proceedings will be strictly prohibited. ${ }^{2}$ The commissions also differ considerably from the courts-martial provided under the Uniform Code of Military Justice (UCMJ). ${ }^{3}$ Courts-martial are appealable on all issues of fact

Copyright $(9) 2002$ by Christopher M. Evans.

1. Military Order of November 13, 2001: Detention, Treatment, and Trial of Certain NonCitizens in the War Against Terrorism, 66 Fed. Reg. 57,833 (Nov. 13, 2001) [hereinafter Military Order]. "Military commissions," as discussed here, are a type of military tribunal, which is a blanket term that also includes courts-martial and courts of inquiry. This distinction is indicated in the Uniform Code of Military Justice:

The provisions of this chapter conferring jurisdiction upon courts-martial do not deprive military commissions, provost courts, or other military tribunals of concurrent jurisdiction with respect to offenders or offenses that by statute or by the law of war may be tried by military commissions, provost courts, or other military tribunals.

10 U.S.C. $\$ 821$ (2000) (emphasis added).

2. Military Order $\S 7(\mathrm{~b})(2)$, supra note 1 , at $57,835-36$. So long as the military commissions are not convened within the territorial jurisdiction of the United States, denial of judicial review will likely pass constitutional muster. See Johnson v. Eisentrager, 339 U.S. 763, 786 (1950) (declining to extend constitutional protections to enemy aliens tried before military commission outside the sovereign territory of the United States for violations of the laws of war). The Supreme Court has "characterized as 'well-established' the 'power of the military to exercise jurisdiction over... enemy belligerents, prisoners of war, or others charged with violating the laws of war."' Id. at 786 (quoting Duncan v. Kahanamoka, 327 U.S. 304, 313-14 (1946)).

3. 10 U.S.C. $\$ \S 801-946(2000)$. 
and law $^{4}$ and, furthermore, adhere to strict rules of evidence. ${ }^{5}$ The commissions, on the other hand, only follow evidentiary guidelines established by the Secretary of Defense in his discretion. ${ }^{6}$

The Military Order creating these commissions reflects the Bush administration's trepidation about prosecuting suspected terrorists through the ordinary criminal justice system, which, it is feared, could lead to substantial delays and even acquittals based on legal technicalities. ${ }^{7}$ President Bush's decision to convene military commissions is also predicated upon the belief that terrorist acts amount to acts of war, and that, accordingly, suspected terrorists should be treated as war criminals. ${ }^{8}$ However, despite the president's repeated pronouncements that the September 11 attacks constituted violations of the law of war, thus empowering him to convene military commissions, ${ }^{9}$ the November 13 Order has been heavily criticized as an unconstitutional expansion of executive authority with the potential for significant abuse. ${ }^{10}$ By contrast, supporters of the commissions maintain that the Military Order is a valid exercise of the president's commander in chief power, and that the president's broad latitude to

4. 10 U.S.C. $\$ 866(c)$.

5. See 10 U.S.C. $\$ 836($ a) (explaining that rules and procedures for courts-martial shall apply principles of law and rules of evidence generally recognized in federal district courts).

6. See Military Order $\S 4(\mathrm{c})(3)$, supra note 1, at 57,835 (stating that evidence will be admitted "as would, in the opinion of the presiding officer of the military commission ... have probative value to a reasonable person"); see also id. § 6(a) (requiring the Secretary of Defense to "issue such orders and regulations as may be necessary to carry out provisions of the order"); see also Department of Defense Military Commission Order No. 1, March 21, 2002, at http:// www.defenselink.mil/news/Mar2002/d20020321ord.pdf (on file with the Duke Law Journal) (detailing procedures for trials by military commission of suspected terrorists, including the rights to a presumption of innocence, to choose counsel, to see the prosecution's evidence, to a public trial, and to remain silent).

7. See Anthony Lewis, Dust in Our Eyes, N.Y. TIMES, Dec. 4, 2001, at A21 (attacking President Bush's order as "extraordinarily ill-drafted").

8. See Military Order $\S 1(\mathrm{e})$, supra note 1, at 57,833 ("International terrorists, including members of al Qaeda, have carried out attacks on the United States ... on a scale that has created a state of armed conflict.").

9. See, e.g., William Glaberson, Support for Bush's Antiterror Plan, N.Y. TimES, Dec. 5, 2001, at B6 (detailing legal grounds for the president's exceedingly broad powers); David E. Sanger, President Defends Military Tribunals, N.Y. TIMES, Nov. 30, 2001, at A1 (quoting the president's statement that "[t]he enemy has declared war on us").

10. See, e.g., Louis Fisher, Bush Can't Rely On FDR Precedent, L.A. TIMES, Dec. 2, 2001, at M3 (arguing that the commissions offer the potential for abuse); Katharine Q. Seelye, In Letter, 300 Law Professors Oppose Tribunals Plan, N.Y. TIMES, Dec. 8, 2001, at A1 (citing a letter that originated at Yale Law School that asserts that the commissions are legally deficient). 
protect national security permits the Bush administration to proclaim war against terrorism. ${ }^{11}$

This Note analyzes the president's legal predicate for authorizing military commissions in response to the attacks on September 11. It concludes that, under Ex parte Quirin, ${ }^{12}$ the president's Order is constitutional. The attacks of September 11 were so catastrophic in their purpose and effect as to constitute "hostile acts" in violation of the laws of war. ${ }^{13}$ Because the attacks commenced an imperfect or "quasi war," the jus in bello was triggered, thus giving the president valid authority to convene the commissions to punish these acts as war crimes under Ex parte Quirin. ${ }^{14}$ This Note maintains, however, that the Military Order is nevertheless an extralegal action because it is inconsistent with existing international law. The laws of war, a subset of the law of nations, apply only to state actors, not to independent terrorist organizations such as those believed to be responsible for the September 11 atrocities. ${ }^{15}$ Despite the administration's attempt to effect a rapid change in customary international law so as to apply the laws of war to nonstate actors, ${ }^{16}$ such a change, even if possible, cannot be made retroactive to the events of September 11. Thus, these commissions lack legal justification under international law.

Part I of this Note briefly summarizes the events of September 11 and then discusses the November 13 Military Order. Part II examines the historical precedent for convening military commissions to prosecute war crimes, and it also considers the various arguments supporting the president's Military Order. Part III describes the unique factual background and holding of Ex parte Quirin, and then analyzes

11. See, e.g., Glaberson, supra note 9, at B6 ("The precedents are overwhelmingly in favor of what the president is doing.").

12. 317 U.S. 1, 48 (1942) (upholding President Roosevelt's power to establish military commissions for violations of the law of war by enemy saboteurs during World War II).

13. See infra Part III.B.

14. See infra notes $105-113$ and accompanying text.

15. See, e.g., Michael Byers, Custom, Power AND the Power of Rules 75 (1999) (discussing the principle of full legal personality in international law and the procedural protections it can invoke).

16. On DOJ Oversight: Preserving Our Freedoms While Defending Against Terrorism: Hearing On Review of Military Terrorism Tribunals Before the Senate Comm. on the Judiciary, 107th Cong. (2001) [hereinafter Hearings] 2001 WL 26187921 (testimony of Scott L. Silliman, Executive Director for the Center on Law, Ethics and National Security, Duke University School of Law). 
the applicability of this opinion to the acts of September 11. Despite the clear differences between the Bush administration's military campaign and the World War II context in which Ex parte Quirin was decided, this Note concludes that this opinion provides a valid constitutional basis for the November 13 Military Order. Part IV discusses the inapplicability of the laws of war to terrorist organizations and the Bush administration's attempt to bring about a sudden change in existing customary international law. Finally, this Note considers the policy implications of using military commissions, as well as the administration's desired change in customary international law. It is argued here that, despite its constitutionality, the Military Order is both unwise and inconsistent with existing law.

\section{The SePtember 11 AtTACKS AND the President's Military ORDER ESTABLISHING MILITARY COMMISSIONS}

The brutal acts of September 11, 2001, closely resembled a surprise enemy attack both in their planning and in their devastating consequences. The destruction of the World Trade Center in New York City and portions of the Pentagon in Washington, D.C., killed approximately three thousand people. ${ }^{17}$ Although parallels have been drawn between these events and Japan's attack on Pearl Harbor in 1941, which left 2,403 people dead, ${ }^{18}$ the attacks of September 11 were worse in terms of the number of casualties suffered, and also marked the largest killing of civilians on the U.S. mainland in the history of the United States. ${ }^{19}$ So grave were these attacks that on September 14, 2001, President Bush proclaimed a national emergency. ${ }^{20}$ The events of September 11 also resulted in a novel and complex political situation. The attack on Pearl Harbor was attributable to a hostile nation then at war with U.S. allies. The suicide missions of September 11, however, were not linked to an identifiable state but, rather, to the loosely knit al Qaeda terrorist network allegedly directed by suspected terrorist Osama bin Laden, and actively supported by the

17. Yochi J. Dreazen, Power-Plant Operators Are Alerted to Threat of Potential Terrorist Plot, WAll ST. J., Feb. 1, 2002, at A4.

18. The ECONOMIST, The New Enemy, Sept. 15, 2001, at 15.

19. The ECOnOmist, The Day the World Changed, Sept. 15, 2001, at 13.

20. Proclamation No. 7463, 66 Fed. Reg. 48,199 (Sept. 14, 2001) reprinted in 50 U.S.C. $\S 1621$ (2000). 
Taliban government in Afghanistan, ${ }^{21}$ a rogue regime never officially recognized by the United States. ${ }^{22}$

President Bush made clear in the aftermath of the attacks that the United States would treat these acts as casus belli, calling them "not acts of terrorism but acts of war." 23 The Military Order of November 13 reiterated the belief that the terrorist attacks were so severe as to have created a state of armed conflict, thus enabling President Bush to establish military commissions to prosecute those responsible. ${ }^{24}$ Specifically, the Order provides:

To protect the United States and its citizens, and for the effective conduct of military operations and prevention of terrorist attacks, it is necessary for individuals subject to this order pursuant to section 2 hereof to be detained, and, when tried, to be tried for violations of the laws of war and other applicable laws by military tribunals. ${ }^{25}$

The Order cites as its legal basis the president's power as commander in chief vested in him by the Constitution and laws of the United States, including the Authorization for Use of Military Force Joint Resolution passed on September 18, 2001, ${ }^{26}$ and sections 821 and 836 of the UCMJ. ${ }^{27}$ The Order also cites President Bush's declaration of a national emergency, and states that "this emergency constitutes an urgent and compelling government interest, and that issuance of this order is necessary to meet the emergency." 28

21. See Elizabeth Bumiller, Bush Pledges Attack on Afghanistan Unless It Surrenders Bin Laden Now, N.Y. Times, Sept. 21, 2001, at A1 (discussing President Bush's address to Congress on September 20, 2001, in which he demanded that the Taliban hand over members of the al Qaeda network to the United States).

22. See Press Release, Office of the White House Press Secretary, Status of Detainees at Guantanamo (Feb. 7, 2002), http://www.whitehouse.gov/news/releases/2002/02/2002020713.html (on file with the Duke Law Journal) [hereinafter Press Release] (explaining that al Qaeda is a foreign terrorist group, and thus its members are not entitled to POW status); Katharine Q. Seelye, In Shift, Bush Says Geneva Rules Fit Taliban Captives, N.Y. TIMES, Feb. 7, 2002, at A1 (explaining President Bush's application of the Geneva convention to Taliban captives but not to al Qaeda detainees).

23. The New Enemy, supra note 18, at 16.

24. See Military Order $\S \S 1(\mathrm{a})-(\mathrm{g})$, supra note 1, at 57,833 (detailing findings in support of military commissions).

25. Id. §1(e).

26. S.J. Res. 23, 107th Cong., 115 Stat. 224 (2001).

27. 10 U.S.C. $\$ \S 821,836(2000)$ (stating that the jurisdiction of courts-martial is nonexclusive, and giving the president the authority to prescribe rules for use in courts-martial and other military tribunals).

28. Military Order $\S 1(\mathrm{~g})$, supra note 1 , at 57,834 . 
During the operations in Afghanistan, which commenced several weeks after September 11, when the Taliban refused to hand bin Laden over to the United States, ${ }^{29}$ U.S. forces captured various members of al Qaeda and the Taliban regime. ${ }^{30}$ Beginning in January, 2002, these captives were transferred to the United States Naval Base at Guantanamo Bay, Cuba, where they remain confined, presumably awaiting trial before military commissions. ${ }^{31}$

\section{ASSERTED SOURCES OF THE PRESIDENT'S AUTHORITY TO CONVENE MILITARY COMMISSIONS}

\section{A. Historical Practice}

The November 13 Military Order was an extraordinary measure. No president had authorized the use of such commissions within the United States in over half a century. The Bush administration's decision to do so, however, is not without precedent. The laws of war have long recognized that military commissions can be convened to prosecute war crimes during an armed conflict." "The [military] commission," as one authority notes, "is simply an instrumentality for the more efficient execution of the laws of war." a long-established history of using military commissions to try those accused of "[v]iolations of the laws and usages of war" dating back to the early years of the Republic. ${ }^{34}$ Throughout the Revolutionary War, a number of enemy spies were tried and convicted before military

29. See Peter Baker, Taliban Preparing Capital for War; Trenches Are Dug, Men Conscripted, WASH. POST, Oct. 2, 2001, at A1 (describing militia fortification of Kabul in anticipation of American forces after the failure of the Taliban to hand over Osama bin Laden to the United States).

30. See John Mintz, Extended Detention in Cuba Mulled, WASH. Post, Feb. 13, 2002, at A16 (envisioning the United States Naval Base at Guantanamo Bay, Cuba, to which al Qaeda captives were sent, as a "terrorist penal colony for years to come").

31. Id.

32. William Winthrop, Military LAW AND PRECEDENTS 330 (2d ed. 1920); see also Ex parte Quirin, 317 U.S. 1, 38-43 (1942) (explaining that the Constitution does not require offenses against the law of war to be tried before a jury). The "laws of war," part of the law of nations, are comprised of both treaties and general, or customary, international law. See Alfred P. Rubin, Remarks at the Annual Meeting of the American Society of International Law (Apr. 25, 1985), in 79 AM. SOC'Y INT'L L. PROC. 109, 111 (1985) (discussing the sources and principles underlying the laws of war in the context of terrorism).

33. WINTHROP, supra note 32, at 330 .

34. Id. at 332 . 
commissions. ${ }^{35}$ George Washington personally ordered the executions of several of those convicted. ${ }^{36}$

Military commissions were also used extensively during the Civil War to try offenses against the laws of war. ${ }^{37}$ One notable trial before a military commission during the Civil War involved Confederate saboteurs who attempted to disrupt the Union war effort by burning down various buildings in New York City. ${ }^{38}$ A Confederate army captain, Robert Kennedy, was found to have attempted, while in disguise, to set fire to several of the city's buildings. ${ }^{39}$ Tried before a military commission in 1865, Kennedy was sentenced to hang for acting as a spy and "undertaking to carry on irregular and unlawful warfare." Another Confederate saboteur, John Y. Beall, was tried before a military commission for his role in the hijacking of a Union vessel and for his unsuccessful attempt to derail a train in New York State-also while in disguise. ${ }^{41}$ Adjudged a spy and a guerilla, Beall was also sentenced to be hanged. ${ }^{42}$ The history of the Civil War is replete with similar cases in which Confederate spies and saboteurs were tried, sentenced and put to death by military commissions. ${ }^{43}$

Constitutionally speaking, presidential authority to establish such commissions, derived from the president's commander in chief powers, is limited. ${ }^{44}$ The Constitution vests the president, as commander in chief, with the power to wage wars that Congress has declared, and to execute all laws passed by Congress defining and punishing offenses committed against the law of nations, including those govern-

35. Ex parte Quirin, 317 U.S. 1, 42 n.14 (1942) (describing numerous cases tried before commissions during the American Revolution); see also WINTHROP, supra note 32, at 832-33 (describing similar trials conducted during the Mexican War).

36. Quirin, 317 U.S. at 42 n.14.

37. See Spencer J. Crona \& Neal A. Richardson, Justice For War Criminals of Invisible Armies: A New Legal and Military Approach to Terrorism, 21 OKLA. CITY U. L. REV. 349, 368 (1996) (describing various instances in which military commissions were used to prosecute Confederate soldiers during the Civil War).

38. Quirin, 317 U.S. at 32 n.10.

39. Id.

40. $I d$.

41. Id.

42. Id.

43. See id. (discussing several examples of Confederate spies tried before military commissions).

44. See U.S. CONST. art. II, § 2 (stating that " $[\mathrm{t}]$ he President shall be Commander in Chief of the Army and Navy of the United States, and of the Militia of the several States, when called into the actual Service of the United States"). 
ing the conduct of war, the jus in bello. ${ }^{45}$ Article 21 of the UCMJ provides that military commissions have "concurrent jurisdiction with respect to offenders or offenses that by statute or by the law of war may be tried by military commissions ... or other military tribunals." 46 Thus, assuming there is an underlying statute defining certain acts as violations of the law of war (or if recognized war crimes were committed during the course of an armed conflict), the president may, in his capacity as commander in chief, constitutionally establish military commissions to punish those acts.

\section{B. The President's Power Over Foreign Affairs}

Congress never formally declared war with regard to the Bush administration's military action in Afghanistan; and because the September 11 attacks are believed to have been committed by terrorist organizations without state sponsorship, it is unclear whether the attacks constitute war crimes. ${ }^{47}$ Thus, the current scenario does not fit easily alongside the historical precedents for the establishment of military commissions to punish war crimes. Officials within the Bush administration have employed a range of arguments with which they seek to justify the November 13 Military Order. The administration has argued, for example, that the United States is in a state of armed conflict, $^{48}$ and that the president has very broad powers to protect national security in wartime. ${ }^{49}$ In making this argument, supporters of the Military Order have cited United States v. Curtiss-Wright Export Corp. $^{50}$ as a plausible basis for President Bush's Order to establish the military commissions. ${ }^{51}$ At issue in Curtiss-Wright was a congressional joint resolution that prohibited arms sales to Paraguay and Bolivia, which were at war, and conditioned its continuance on President Roosevelt's issuance of a proclamation as to its effect in helping to restore peace to that region. ${ }^{52}$ The Curtiss-Wright Corporation, charged

\footnotetext{
45. Quirin, 317 U.S. at 26.

46. 10 U.S.C. $\$ 821$ (2000).

47. Rubin, supra note 32, at 111.

48. See, e.g., Military Order $\S 1($ a), supra note 1, at 57,833 (stating that the terrorist attacks have "created a state of armed conflict").

49. Glaberson, supra note 9, at B6 (describing lawyers' efforts to assemble a "talkingpoints brief in defense of the administration's actions").

50. 299 U.S. 304 (1936).

51. Glaberson, supra note 9, at B6 (citing a recent brief written by former Deputy Attorney General George Terwilliger in support of the Order).

52. 299 U.S. at 314-15.
} 
with violating the arms embargo, argued that because the joint resolution was conditioned on a discretionary presidential proclamation regarding a foreign conflict, it constituted an unconstitutional delegation of legislative authority to the executive. ${ }^{53}$

The Court drew a dichotomy between the powers of the federal government over foreign relations on the one hand, and domestic affairs on the other. "The broad statement that the federal government can exercise no powers except those specifically enumerated in the Constitution," Justice Sutherland wrote, "is categorically true only in respect of our internal affairs." ${ }^{, 4}$ Curtiss-Wright thus established the president as the "sole organ of the nation in its external relations, and its sole representative with foreign nations." 55 Thus, according to Curtiss-Wright, the president's power to act as the federal government's sole organ in external affairs does not, unlike the domestic sphere, require congressional authorization. ${ }^{56}$ Bush administration lawyers contend that this plenary and exclusive power over foreign affairs is a valid basis upon which the president can convene military commissions. $^{57}$

This argument, however, is not easily applied to the present situation. First, whether or not the United States is "at war," as some have maintained, is debatable. It thus cannot be assumed automatically that the president was acting in the realm of "external affairs" when he issued the November 13 Order, as the "sole organ" theory would require. ${ }^{58}$ Justice Sutherland emphasized that the president's "sole organ" power is limited to foreign affairs whereas in domestic affairs the president is constrained by the need for congressional authorization. ${ }^{59}$ It is beyond this Note's scope to categorize precisely where the November 13 Military Order falls on the spectrum between domestic and foreign affairs, but it does seem to have some implications for the domestic sphere. For example, the Order has a law en-

53. Id. at 315 .

54. Id. at $315-16$.

55. Id. at 319 .

56. Id. at 320; see also LAURENCE H. TRIBE, AMERICAN CONSTITUTIONAL LAW § 402, at 213 (2d ed. 1988) (stating that, in the domestic sphere, the president's constitutional role "is thus largely ancillary to that of Congress").

57. See Glaberson, supra note 9, at B6 ("[S]upporters of the measures have begun to outline a legal defense of the actions, saying that the president has broad powers to protect national security in wartime....").

58. Curtiss-Wright, 299 U.S. at 319.

59. See id. at 315-16 (distinguishing the scope of the exercise of general executive power over internal affairs from the exercise of power over foreign affairs). 
forcement component, as it provides for the prosecution by military commissions of violations of the laws of war and "other applicable laws." ${ }^{60}$ Furthermore, other departments and agencies such as the FBI are obliged, to the maximum extent permitted by law, to assist the Secretary of Defense "as he may request to implement this order.", This provision, which pertains not only to external relations but also to domestic security, may serve as a basis for the detention of suspected terrorists who may be turned over to the Department of Defense for trial before a commission. Therefore, in contrast to the presidential proclamation at issue in Curtiss-Wright, which fit clearly into the realm of external relations, President Bush's Order has significant implications for domestic affairs. Curtiss-Wright's "sole organ" theory is, accordingly, inapplicable here.

\section{C. "Crisis Government" and Prerogative Power}

Proponents of the Military Order have, similarly, invoked the concept of crisis government ${ }^{62}$ and the need for undefined power in the national government during certain crises. ${ }^{63}$ This theory is based on the notion of prerogative power applied to presidential actions of an extraconstitutional nature. The concept was first articulated by Alexander Hamilton in The Federalist No. 23, in which he asserted:

The circumstances that endanger the safety of nations are infinite, and for this reason no constitutional shackles can wisely be imposed on the power to which the care of it is committed. This power ought to be co-extensive with all the possible combinations of such circumstances; and ought to be under the direction of the same councils which are appointed to preside over the common defense. ${ }^{64}$

\footnotetext{
60. Military Order $\S 1(\mathrm{e})$, supra note 1 , at 57,833 .

61. Id. at 57,385 .

62. For a discussion of crisis government, see Martin S. Sheffer, Does Absolute Power Corrupt Absolutely?, 24 OKLA. CiTY U. L. REV. 233, 233-34 (1999) :

... [R]eality ... demonstrates that war and peace are not the same thing, cannot coexist in the same place at the same time, and constitutional provisions applicable in time of peace may not be equally applicable in time of war. In other words, the Constitution does not function normally in abnormal times.

See also Edward S. Corwin, The President: OfFICE AND Powers, 1787-1957, at 3 (4th ed. 1957) (discussing how the indefiniteness of executive power makes it particularly responsive to national emergencies).

63. See Glaberson, supra note 9, at B6 (explaining the legal justifications offered by supporters of the "[second] Bush Administration's antiterrorism crackdown").

64. The Federalist No. 23, at 153 (Alexander Hamilton) (Clinton Rossiter ed., 1961).
} 
The theory of crisis government as a basis for the Military Order is, however, palpably inapposite here. Although President Bush proclaimed a national emergency in the wake of the attacks, ${ }^{65}$ such actions or statements cannot serve as a valid legal predicate for the November 13 Order. "The Constitution," as one scholar has explained, "recognizes no 'emergency powers,' whether for the President, or for other branches of the federal government. ${ }^{, 66}$ Even in declared emergencies, the president's powers are limited to those either conferred by the Constitution or authorized by Congress. ${ }^{67}$ In Ex parte Milli$g^{g a n}{ }^{68}$ the Supreme Court rejected the idea that emergency powers, even during times of armed conflict, could be a basis for the president's authority to establish military commissions to prosecute war crimes. "No doctrine," wrote Justice Davis, "involving more pernicious consequences, was ever invented ... than that any of [the Constitution's] provisions can be suspended during any of the great exigencies of government." ${ }^{, 70}$ Milligan involved the issue of trying a U.S. citizen before a commission during the Civil War when courts of law were open and available, and is therefore more significant here because of the politically charged context in which it was decided than for its actual holding. ${ }^{71}$ Nevertheless, Milligan's rejection of emergency powers as a basis for the president's authority to establish military commissions remains binding.

\section{The CONSTITUTIONALITY OF THE NOVEMBER 13 MilitaRY ORDER UNDER EX PARTE QUIRIN}

\section{A. The Legal Precedent}

Both proponents and critics of the Bush administration's plan to use military commissions have invoked the Supreme Court's decision

65. Proclamation No. 7463, 66 Fed. Reg. 48,199 (Sept. 14, 2001), reprinted in 50 U.S.C. $\S 1621$ (West, WESTLAW through P.L. 107-89).

66. Louis Henkin, Foreign AfFAirs AND the U.S. CONSTITUTION 53 (2d ed. 1996).

67. $I d$.

68. 71 U.S. (4 Wall.) 2 (1866).

69. Id. at $118-27$.

70. Id. at 121 .

71. The November 13 Military Order applies only to noncitizens. Military Order §2, supra note 1 , at 57,833-34. The current situation is also distinguishable from the Civil War context in which Milligan was decided because it is unclear whether the United States is technically at war. See infra notes $96-98$ and accompanying text. 
in Ex parte Quirin, ${ }^{72}$ upholding President Roosevelt's authority to establish military commissions in the United States for the prosecution of war crimes during the Second World War. Proponents cite Quirin as a clear affirmation of the president's power to convene such commissions for violations of the laws of war. ${ }^{73}$ Skeptics of the November 13 Order, on the other hand, are careful to distinguish the specific factual context in which Quirin was decided from the present setting. ${ }^{74}$ A careful analysis of Quirin is therefore necessary, as the constitutionality of President Bush's Military Order, if challenged in court, will likely hinge in large part on how this decision is interpreted.

Quirin involved a petition for habeas corpus, filed by suspected German saboteurs captured within the United States during the Second World War, to challenge the constitutionality of their trial by military commission when the federal district courts were open and available. The saboteurs landed in two teams on July 12 and 17, 1942, off the shores of Long Island and Florida, respectively. ${ }^{75}$ All were agents of Nazi Germany. ${ }^{76}$ They arrived armed with various explosive devices intending to disrupt America's war effort by destroying transportation and industrial facilities throughout the United States. ${ }^{77}$ The saboteurs were, however, apprehended and taken into custody by the FBI. $^{78}$ Based on concerns similar to those of the Bush administration about proceeding through the criminal justice system, Attorney General Francis Biddle prepared a memorandum for the president recommending that, as commander in chief, he appoint a special military commission to prosecute the suspects for violations of the law of war. ${ }^{79}$ Thus, on July 2, 1942, President Roosevelt issued an order es-

72. 317 U.S. 1, 36-37 (1942) (upholding a trial of alleged unlawful combatants ["enemy belligerents"] before a military commission for violations of the laws of war upon entry into the United States in a time of war for the purpose of executing hostile acts).

73. Glaberson, supra note 9 , at B6.

74. See, e.g., Fisher, supra note 10, at M3 (contrasting the World War II setting in which President Roosevelt established commissions to prosecute the saboteurs with the present circumstances).

75. Ex parte Quirin, 317 U.S. 1, 21 (1942).

76. Id. at 20-21.

77. Michal R. Belknap, The Supreme Court Goes to War: The Meaning and Implications of the Nazi Saboteur Case, 89 MIL. L. REV. 59, 62 (1980).

78. Id.

79. Francis BIDDle, IN BRIEF AUTHORITY 328-30 (1962); see also Belknap, supra note 77 , at 75 (“'The time may now have come,' the government's brief observed, 'when the exigencies of ... war must force a recognition that every foot of this country is within the theatre of operations.' The test of whether or not the civil courts were open to punish crimes, it was argued, was now 'unrealistic.”' (citing Brief for Respondent, Burger v. Cox, 317 U.S. 1 (1942))). 
tablishing a military commission for the trial of the saboteurs "for offenses against the law of war and the Articles of War" adopted by Congress. ${ }^{80}$ Roosevelt then issued a Proclamation declaring that "all persons who are . . citizens ... of any nation at war with the United States ... and who during time of war ... are charged with ... violations of the law of war, shall be subject to the law of war and to the jurisdiction of military tribunals." ${ }^{\text {1 }}$ The military commission convened on July 8,1942 , and proceeded to try the eight saboteurs, ${ }^{82}$ six of whom were eventually sentenced to death. ${ }^{83}$

Chief Justice Stone's opinion in Quirin dismissed the petitioners' argument, based on Ex parte Milligan, that as long as civil courts were available, the president was without authority to establish military commissions. ${ }^{84}$ The Court stated that the Constitution does not require that offenses against the law of war be tried before a jury. ${ }^{85}$ The opinion also established at the outset the presumption that presidential actions taken pursuant to the commander in chief power during wartime are valid, unless those actions are clearly in conflict with the Constitution. ${ }^{86}$ Chief Justice Stone wrote, "[T]he detention and trial of petitioners-ordered by the President in the declared exercise of his powers as Commander in Chief of the Army in time of war and of grave public danger-are not to be set aside by the courts without the clear conviction" that they are in violation of the Constitution or laws of the United States. ${ }^{87}$

The Court found no such conflict with regard to President Roosevelt's Military Order, as it was promulgated during wartime pursuant to Articles of War adopted by Congress. ${ }^{88}$ The Court then went on to determine who may be tried before military commissions for violations of the law of war. The Court distinguished carefully between "lawful combatants," who are subject to capture and detention as

\footnotetext{
80. 7 Fed. Reg. 5,103, 5,103 (1942); see also Quirin, 317 U.S. at 22 (summarizing the president's actions in appointing a military commission).

81. Proclamation No. 2561, 7 Fed. Reg. 5,101, 5,101 (1942); see also Quirin, 317 U.S. at 2223 (discussing the Proclamation).

82. Quirin, 317 U.S. at 23-24.

83. BIDDLE, supra note 79 , at 339.

84. Quirin, 317 U.S. at 24-25.

85. Id. at 40 .

86. Id. at 25 .

87. Id. (emphasis added).

88. Id. at 28 .
} 
prisoners of war by opposing military forces, and "unlawful combatants" who may be brought before military commissions:

The spy who secretly and without uniform passes the military lines of a belligerent in time of war, seeking to gather military information and communicate it to the enemy, or an enemy combatant who without uniform comes secretly through the lines for the purpose of waging war by destruction of life or property, are familiar examples of belligerents who are generally deemed... offenders against the law of war subject to trial and punishment by military tribunals. ${ }^{89}$

The eight German saboteurs had been apprehended wearing civilian clothes rather than their military uniforms "during time of war," ${ }^{90}$ with the intent to commit "hostile acts involving destruction of life or property," ${ }^{, 11}$ and were acting as agents of an enemy nation at war with the United States-the Third Reich. ${ }^{92}$ The saboteurs were accordingly found to be unlawful combatants, triable before a military commission for violations of the law of war. ${ }^{93}$

Thus, under Quirin, the requirements for a suspect to be an unlawful combatant subject to trial by military commission for violations of the law of war may be summarized as follows: There must be entry into the United States in a time of war for the purpose of committing hostile acts by "enemy belligerents" disguised in civilian clothing instead of their military uniforms. ${ }^{94}$ It should be observed that "hostile acts," as defined in Quirin, are not limited to assaults on military targets. ${ }^{95}$

\section{B. The Applicability of Ex parte Quirin to the Attacks of September 11}

It is clear from the preceding discussion of Quirin that the situation in which President Roosevelt authorized military commissions to be established was entirely different from the context in which President Bush promulgated his Military Order on November 13. President Roosevelt authorized commissions in the midst of a war declared by Congress, and the eight German saboteurs were acting as agents of

\footnotetext{
89. Id. at 31 .

90. Id. at 35

91. Id.

92. Id. at 21-22.

93. Id. at 46.

94. Id. at 37.

95. Id.
} 
a declared enemy state. Here, by contrast, the United States was not in a state of armed conflict on the morning of September 11, prior to the attacks. Moreover, it is unclear whether the suspected terrorists were sponsored by any recognized state. ${ }^{96}$ Critics of the Bush administration's Military Order thus contend that because the United States was not at war as of the morning of September 11, the attacks cannot be considered violations of the law of war. ${ }^{97}$ It is maintained, therefore, that Quirin is inapposite because of the unique factual situation in which it was decided. ${ }^{98}$ This argument is predicated on the idea that a declared war, or at least a state of armed conflict, must already exist for there to be a violation of the law of war." "The notion of war crimes," one scholar has explained, "presupposes a war ...."100

Critics of the November 13 Order also distinguish Quirin because President Roosevelt, unlike President Bush, acted pursuant to an express congressional declaration of war. ${ }^{101}$ Thus, under Justice Jackson's typology of presidential power in his oft-cited concurrence in Youngstown Sheet \& Tube Co. v. Sawyer, ${ }^{102}$ President Roosevelt's authority was at its zenith, as he was acting pursuant to an express congressional authorization..$^{103}$ It is argued, therefore, that even if one were to accept the assertion that the United States was engaged in some sort of armed conflict with such groups as al Qaeda prior to the September 11 attacks, President Bush lacks the clear authority that was available to President Roosevelt. ${ }^{104}$

Despite these obvious differences, a close reading of Quirin reveals that it may nevertheless serve as a valid predicate for the Bush

\footnotetext{
96. The issue of state sponsorship is addressed in Part IV, infra.

97. See Hearings, supra note 16 (testimony of Scott L. Silliman).

98. See id.; Fisher, supra note 10, at M3 (drawing attention to the unique wartime situation in which Quirin was decided).

99. Hearings, supra note 16 (testimony of Scott L. Silliman).

100. Donald A. Wells, WAR Crimes ANd LaWs OF WAR 41 (2d ed. 1991).

101. See Hearings, supra note 16 (testimony of Scott L. Silliman).

102. 343 U.S. 579 (1952).

103. See id. at 635 (Jackson, J., concurring) (stating that presidential power is at its greatest when exercised in conjunction with Congressional authority). According to Justice Jackson's typology, when the president acts pursuant to either an explicit or implied congressional authorization, his authority is at its maximum. Id. at 635. When the president acts without either a congressional grant or denial of authority, his power falls within a "zone of twilight in which he and Congress may have concurrent authority, or in which its distribution is uncertain." Id. at 637. However, when the president acts incompatibly with the express or implied will of Congress, his authority is at its "lowest ebb, for then he can rely only upon his own constitutional powers minus any constitutional powers of Congress over the matter." Id.
}

104. See Hearings, supra note 16 (testimony of Scott L. Silliman). 
administration's Military Order of November 13. The attacks of September 11 constituted hostile acts so severe in both their purpose and their effect as to be war crimes; these acts therefore commenced a state of armed conflict, thus giving the president the authority to establish military commissions to punish the acts as violations of the law of war. While there has not been a congressional declaration of war as there was in Quirin, the United States was, as of the attacks, engaged - and has remained engaged - in a state of "quasi war."105

The text of the November 13 Military Order indicates that it was promulgated partly on the notion that the attacks of September 11 were so severe that they rose to the level of "hostile acts" under the law of war, thus giving rise to an armed conflict. Section 1(a) of the Order states that "[i]nternational terrorists, including members of al Qaeda, have carried out attacks on United States diplomatic and military personnel ... within the United States on a scale that has created a state of armed conflict that requires the use of the United States Armed Forces." 106 This idea is based upon the argument that catastrophic terrorist acts can be so grave as to rise to the level of war crimes. The theory is, essentially, that terrorist attacks constitute acts of aggression, target innocent civilians for indiscriminate assault, and are carried out by irregular saboteur forces that neither identify themselves nor openly bear arms. ${ }^{107}$ Terrorist acts, thus defined, are not functionally different from the crimes for which, for example, the eight saboteurs in Quirin were charged and prosecuted. Such acts, it is maintained, should be regarded as war crimes or crimes against humanity. ${ }^{108}$ President Bush has both implicitly and explicitly made this argument in various public pronouncements since September 11. "Non-U.S. citizens who plan and/or commit mass murder," the president has asserted, "are more than criminal suspects. They are unlawful combatants who seek to destroy our country and our way of life." 109 It is highly significant, moreover, that the United States' NATO allies appear to have recognized the September 11 attacks as the inception of an armed conflict. In response to the September 11

105. See generally Fisher, supra note 10 (criticizing analogies between the Bush and Roosevelt decisions to authorize military commissions).

106. Military Order $\$ 1$ (a), supra note 1, at 833 (emphasis added).

107. See Crona \& Richardson, supra note 37, at 359 (citing YOSSEF BODANSKY, TARGET AMERICAN \& THE WEST 2-3 (1993)).

108. See id. at 351 (citing the U.S. government's opening statement, during the second World Trade Center bombing trial, that "[t]his is a case involving a war").

109. Sanger, supra note 9, at A1. 
attacks, NATO invoked Article 5 of its Charter on mutual defense for the first time in its history, which binds the signatories to regard an attack on one member as an attack on all. ${ }^{110}$

The assertion that the terrorist acts of September 11 could rise to the level of war crimes or crimes against humanity finds support in accepted principles of the law of war. In his famous treatise on military law and the law of war, William Winthrop explained, "[i]t is forbidden by the usages of civilized nations to take the lives of, or commit violence against, non-combatants and private individuals not in arms, including women and children ...."111 Such acts, the treatise explains, constitute illegal warfare. ${ }^{112}$ This well-established principle is based on the writings of early war theoreticians who had proposed bans on the use of incendiaries, as well as the strategy of making deliberate attacks on civilian populations. ${ }^{113}$

There can be little doubt, therefore, that according to accepted principles of the laws of war, ${ }^{114}$ the attacks of September 11 were severe enough in terms of their purpose and effect to constitute war crimes. However, under Quirin, for the perpetrators of these assaults to have the status of unlawful belligerents, and thus be subject to trial by military commissions, the acts must have been committed "in time of war." As the Court in Quirin explained, "those who during time of war pass surreptitiously from enemy territory into our own ... for the commission of hostile acts involving destruction of life or property, have the status of unlawful combatants punishable as such by military commission." 116

It is widely accepted that the assailants of September 11 and their accomplices entered the United States for the purpose of committing "hostile acts involving destruction of life or property" on a horrendous scale, and tragically were successful. Under Quirin, therefore, these attacks would seem to constitute "hostile and war-like act[s]""17

\footnotetext{
110. The Day the World Changed, supra note 19, at 14.

111. WINTHROP, supra note 32 , at 315.

112. Id.

113. See WELls, supra note 100, at 73 (noting, for example, that "[e]arly Roman Catholic Church Councils had proposed bans on the use of incendiaries, poisons, and the crossbow, as well as against the strategy of making deliberate war on civilians").

114. See id. at 73-85 (explaining general tenets of the laws of war); WINTHROP, supra note 32, at 315-21 (same).

115. Ex parte Quirin, 317 U.S. 1, 37 (1942).

116. Id. at 35 .

117. Id. at 37 .
} 
capable of subjecting those responsible to punishment by military commissions. The real issue, then, is whether the attacks can be considered to have been executed "in time of war" (thus giving those responsible the status of "unlawful combatants") as Quirin would seem to require.

In describing the German saboteurs' unlawful warlike acts, the Quirin Court held that, "[b]y passing our boundaries for such [unlawful] purposes without uniform or other emblem signifying their belligerent status ... such enemies become unlawful belligerents subject to trial and punishment [by military commission]."118 This statement, as applied to the facts in Quirin, meant that once the saboteurs had passed surreptitiously and in civilian clothing into the United States with the intent to commit hostile and warlike acts, they acquired the status of unlawful belligerents, even though they were apprehended before they could execute their scheme. Applying this framework to the events of September 11, it would appear that once the terrorists boarded their respective planes with the intent to commit hostile, warlike acts, they similarly acquired the status of unlawful belligerents.

In Quirin, of course, the existence of a declared war meant that the saboteurs' unlawful acts were necessarily committed in wartime. However, as one international law scholar has argued, "as soon as the activities of any armed group reach the level at which the laws of war should apply, those laws must apply even if the enemy army is called 'terrorist' or engages in acts which violate the laws of war.",119 As discussed previously, there can be little doubt that the September 11 attacks were severe enough to constitute war crimes or crimes against humanity. ${ }^{120}$ These acts of aggression, as the November 13 Order states, created a state of armed conflict. ${ }^{121}$ Therefore, according to the analytical framework of Quirin, upon the event of the plane hijackings, the terrorists and their accomplices became unlawful belligerents, punishable by military commissions for offenses against the law of war. The Court in Quirin stated that "[t]he offense was complete when with that purpose [the saboteurs] entered... our territory in time of war . ..."122 On September 11, the attacks gave rise to a state

118. Id. (emphasis added).

119. Rubin, supra note 32, at 110.

120. See supra notes 105-116 and accompanying text.

121. Military Order $\S 1$ (a), supra note 1, at 57,833.

122. Quirin, 317 U.S. at 38. 
of armed conflict and thus, technically, mark the inception of this resulting state of conflict. Therefore, the attacks, properly considered, are violations of the law of war. The ensuing state of armed conflict cannot be considered separately from the events that began the conflict.

Still, there are significant differences between the state of armed conflict in which the United States is presently engaged and the official wartime situation in which President Roosevelt authorized the use of military commissions. Despite the president's proclaimed "war on terrorism, ${ }^{, 123}$ the United States is not officially at war, as critics of the Military Order have been quick to observe. Thus, while President Roosevelt was acting pursuant to express congressional authority and, therefore, according to Justice Jackson's concurring opinion in Youngstown, was at the apogee of his power, President Bush's authority to convene commissions is less certain. ${ }^{124}$ Quirin nevertheless provides a valid constitutional basis for the president's Order. While President Bush lacks a congressional declaration of war, Congress did pass, and President Bush signed, the Authorization for Use of Military Force Joint Resolution, which enables the president to use "all necessary and appropriate force against those nations, organizations, or persons" that he determines planned or aided the terrorist attacks of September $11 .{ }^{125}$

Presidents have been able to rely on such congressional statements as the basis for their authority in armed conflicts even without an official declaration of war, as demonstrated in Vietnam with the Gulf of Tonkin Resolution. ${ }^{126}$ The power of Congress to declare war has long been recognized as the power to define war. In Talbot $v$. Seeman, ${ }^{127}$ for example, the Supreme Court recognized Congress's power to declare a "partial war" targeted at a specific form of enemy aggression, even while the United States was not "at war" with the enemy nation in the traditional sense. ${ }^{128}$ In Talbot, the Court ruled on

123. For a discussion of President Bush's objectives, see Bumiller, supra note 21, at A1.

124. See supra notes $101-105$ and accompanying text.

125. S.J. Res. 23, 107th Cong., 115 Stat. 224 (2001).

126. HENKIN, supra note 66, at 47; see also Sheffer, supra note 62, at 281 (arguing that the Tonkin Gulf Resolution was the "functional equivalent" of a declaration of war).

127. 5 U.S. (1 Cranch) 1 (1801).

128. Id. at 15; see also Crona \& Richardson, supra note 37, at 361 ("A reasonable inference from Chief Justice Marshall's analysis [in Talbot] is that the War Powers Clause enabled Congress to authorize hostilities against a particular kind of predatory military activity without declaring a full-scale war against a nation in the traditional sense.”). 
certain measures Congress had adopted to deal with French privateers who were preying on American commercial vessels. Chief Justice Marshall held that "[C]ongress may authorize general hostilities ... or partial hostilities, in which case the laws of war, so far as they actually apply to our situation, must be noticed." ${ }^{129}$ Therefore, according to Talbot, the Constitution seems to recognize imperfect, or "quasi," war. The War Powers Clause ${ }^{130}$ allows Congress to authorize the use of force against specific types of predatory military activities without declaring a full-scale war. ${ }^{131}$

It is established, moreover, that in response to an attack upon the United States, such as that which occurred on September 11, the president has unquestioned constitutional authority as commander in chief to defend the nation. ${ }^{132}$ Without a congressional declaration of war, or even other authorization from Congress, the power of the president to engage the armed forces in conflict to "repel invasion" is clearly established. ${ }^{133}$ Congressional authorization to respond to an attack on the United States is simply assumed. ${ }^{134}$ Thus, in such circumstances, the president has the authority not only to repel the attack, but also to wage to whatever extent necessary the war imposed on the United States.

Justice Stone's opinion in Quirin seems to contemplate the president's authority to punish violations of the law of war through military commissions, even in the absence of an express declaration of war by Congress. Nowhere in the opinion is there any mention of the need for a congressional declaration of war. It would be strange, furthermore, if in light of the Supreme Court's recognition of imperfect war, Quirin was confined only to expressly declared wars. That the Court in Quirin may have contemplated the president's power to establish military commissions in situations other than in an officially

129. Talbot, 5 U.S. (1 Cranch) at 28.

130. U.S. Const. art. I, § 8, cl. 11 ("The Congress shall have Power .... [t]o declare War, grant Letters of Marque and Reprisal, and make Rules concerning Captures on Land and Water.").

131. Talbot, 5 U.S. (1 Cranch) at 28.

132. See HENKIN, supra note 66, at 47-48 ("Without awaiting a Congressional declaration of war, or other authorization from Congress, the power of the President to use the troops and do anything else necessary to repel invasion is beyond question.").

133. The Prize Cases, 67 U.S. (2 Black) 635, 668 (1862) ("If a war be made by invasion of a foreign nation, the President is not only authorized but bound to resist by force.").

134. HENKIN, supra note 66, at 48.

135. See The Prize Cases, 67 U.S. (2 Black) at 668 ("He does not initiate the war, but is bound to accept the challenge without waiting for any special legislative authority."). 
declared war also seems plausible because of an ambiguous statement toward the end of the opinion, which leaves room for a broad reading of the case. "We have no occasion now," said the Court, "to define with meticulous care the ultimate boundaries of the jurisdiction of military tribunals to try persons according to the law of war." ${ }^{, 136}$ It is important to note that because the customary laws of war apply to cases of international armed conflict as well as to officially declared war, an actual declaration of war is not an essential condition for the application of this body of law. ${ }^{137}$

Thus, the broadly worded Joint Resolution of September 14 seems to have put the president in a very strong position by giving him the authority to conduct a constitutionally recognized "quasi war." President Bush therefore has the constitutional power under Quirin to establish military commissions to punish offenses against the law of war, even without an official declaration by Congress.

\section{REMAINING OBSTACLES TO THE USE OF COMMISSIONS: EXTRALEGALITY UNDER CUSTOMARY INTERNATIONAL LAW AND POLICY RAMIFICATIONS}

\section{A. Inconsistency With International Law}

While the Bush administration's Military Order technically meets the constitutional requirements set forth in Ex parte Quirin, it is inconsistent with international law, of which the laws of war are a subset. Under existing international law, only states are recognized as having legal "personality" - that is, the capacity to hold rights and to be subject to obligations within the international legal system. ${ }^{138}$ The laws of war, therefore, apply only to state actors, not to individuals. ${ }^{139}$ Despite the increase in incidents of international terrorism over the past several decades, the laws of war do not make special provision

136. Ex parte Quirin, 317 U.S. 1, 45-46 (1942) ("We hold only that those particular acts constitute an offense against the law of war which the Constitution authorizes to be tried by military commission.") (emphasis added).

137. U.S. DeP'T of the ARMy, Field Manual No. 27-10: The LaW of LAND WARfare 8 (1956).

138. BYERS, supra note 15 , at 75.

139. See W.J. Fenrick, Remarks at the Annual Meeting of the American Society of International Law (Apr. 25, 1985), in 79 AM. SOC'Y INT'L L. Proc. 112, 114 (1985) (“Except in the near nonexistent case of the leveé on mass, individuals have no legal right to assume combatant status on their own initiative. Individuals may perform the most monstrous acts for what they consider to be the purest of motives."). 
for terrorists or terrorist activities. ${ }^{140}$ Thus, for individuals to be tried and punished for offenses against the laws of war, they must be acting as agents of a recognized state. ${ }^{141}$ In Quirin, for example, the eight saboteurs were agents of Nazi Germany and could thus be tried for offenses in violation of the law of war. ${ }^{142}$ Those supposedly responsible for the attacks on September 11, by contrast, were acting not as agents of any recognized state but, rather, as members of an independent terrorist organization. ${ }^{143}$ These suspects therefore cannot, consistent with existing international law, be tried before military commissions for violating the laws of war.

Recognizing this obstacle, the Bush administration is seeking to effect a rapid change in customary international law so that the laws of war can be made applicable to such nonstate actors as the members of al Qaeda. ${ }^{144}$ The United States cannot, however, effectuate such a change unilaterally. Customary international law results from a consensual process of consistent and general practice among states, which they follow out of a sense of legal obligation, or opinio juris. ${ }^{145} \mathrm{New}$ customary rules (e.g., the recognition that the law of war applies to individual nonstate actors) must derive from the state practice of a large number of states. ${ }^{146}$ States creating new customary rules must intend for those rules to exist and must adjust their practices accordingly. ${ }^{147}$

While a new rule recognizing that the laws of war may be applied to independent terrorist organizations may be evolving, no consistent

140. Frits Kalshoven, Remarks at the Annual Meeting of the American Society of International Law (Apr. 25, 1985), in 79 AM. SOC'Y INT'L L. PrOC. 114, 115 (1985).

141. See, e.g., Quirin, 317 U.S. at 35-36 (holding that saboteurs acting as agents for the Third Reich could be prosecuted for violations of the laws of war).

142. Id.

143. See Bumiller, supra note 21, at A1 (stating that President Bush declared that al Qaeda was a "terrorist network that ... involved thousands of people in more than 60 countries"). While al Qaeda is believed to have been supported by the Taliban regime in Afghanistan, id., the Taliban was considered a rogue regime and was never officially recognized by the United States. See AHMEd RASHID, TALIBAN 118 (2000) ("Mullah Omar ... periodically offer[ed] the U.S. and U.N. an end to poppy cultivation, if the Taliban were given international recognition the first time a movement controlling 90 percent of a country had offered the international community such an option.").

144. Hearings, supra note 16 (testimony of Scott L. Silliman).

145. RESTATEMENT (THIRD) OF FOREIGN RELATIONS LAW § 102(2) (1986); BYERS, supra note 15 , at 130 .

146. BYERS, supra note 15 , at 193.

147. Id. 
and general state practice has yet emerged. ${ }^{148}$ To apply the laws of war to nonstate terrorist groups is to recognize implicitly that such entities have international legal personality. ${ }^{149}$ The Bush administration has announced, however, that the prisoners held at the U.S. Naval Base in Guantanamo are not legally entitled to Prisoner of War (POW) status under the Third Geneva Convention of 1949, although the detainees will be treated "in a manner consistent with the principles" of the Convention. ${ }^{150}$ As a justification for the denial of POW status for the al Qaeda suspects, the Bush administration has announced that "Al-Qaeda is not a state party to the Geneva Convention; it is a foreign terrorist group. As such, its members are not entitled to POW status." ${ }^{151}$ Not only is this decision lacking in precedent, ${ }^{152}$ it applies existing rules of international law, which recognize only states as having legal personality, to what the Bush administration is seeking to establish as a new customary rule. No consistent and general state

148. A declared practice by one state alone could, if acquiesced to by other states, constitute a modification of customary international law. Id. at 133 (citing Case Concerning Military and Paramilitary Activities In and Against Nicaragua, 1986 I.C.J. 109 (para. 207)). The United States, however, is the only nation currently following this practice, and has been criticized for it. See, e.g., Thalif Deen, Rights: Int'l Bodies Oppose U.S., Western Curbs on Freedom, INTER PRESS SERV., Nov. 29, 2001 (detailing the concerns of Mary Robinson, U.N. High Commissioner for Human Rights, over planned trials before military commissions); Betsy Pisik, U.S. Ambassador Brushes Off Rights Concerns, WASH. TIMES, Nov. 30, 2001, at A17 (describing sharp criticism abroad of the November 13 Military Order establishing commissions); Sebastian Rotella, SaudiBacked Web Supports Terrorism, Book Asserts France: "Forbidden Truth" Details Kingdom's Role in Funding Bin Laden and Contends Geopolitical Concerns Have Influenced U.S. Policy, L.A. TIMES, Jan. 13, 2002, at A11 (noting the French government's criticism of the U.S. plan to prosecute suspected terrorists before military commissions).

149. See BYERS, supra note 15, at 75:

In the international legal system the principle of personality has the consequence that only those individuals or entities which have international legal personality are entitled to participate in the process of customary international law, and only those individuals or entities which have full international legal personality are entitled to participate fully in that process.

150. Press Release, supra note 22 (emphasis added). The Bush administration is presumably seeking to avoid classifying the Taliban and al Qaeda suspects as POWs because such status would, under Article 102 of the Third Geneva Convention of 1949, prevent them from being tried by military commissions. Article 102 states "A prisoner of war can be validly sentenced only if the sentence has been pronounced by the same courts according to the same procedure as in the case of members of the armed forces of the Detaining Power." Geneva Convention Relative to the Treatment of Prisoners of War, Aug. 12, 1949, art. 102, 75 U.N.T.S. 135. Therefore, POW status in this case would entitle the Guantanamo suspects to trial by courts-martial, pursuant to the UCMJ and entailing the full protections afforded to American military personnel. Id.

151. Press Release, supra note 22.

152. See Seelye, supra note 22, at A1 (discussing the Pentagon's decision in Vietnam to grant the Vietcong POW status). 
practice recognizing the legal personality of independent terrorist groups can thus be determined to have evolved.

Even if such a custom does take shape, however, it cannot be applied retroactively through the November 13 Military Order to the acts of September 11 without violating the Ex Post Facto Clause of the Constitution. ${ }^{153}$ Customary international law is incorporated into the federal common law. ${ }^{154}$ To apply a customary rule retroactively, therefore, would quite clearly constitute an ex post facto law, as the laws of war at the time of the September 11 attacks did not apply to nonstate entities. The Order, as currently written, will thus remain an extralegal action under existing international law.

\section{B. Policy Implications Concerning the Use of Military Commissions}

Assuming the possibility that the United States could bring about a rapid change in existing customary international law so that the law of war could be applied to nonstate terrorist groups, there are serious policy considerations that mitigate against doing so. As one scholar has noted, "One man's terrorist is another's freedom fighter." ${ }^{155}$ Such a rule would open nongovernmental organizations, including relief agencies, to politically motivated prosecutions throughout the developing world. ${ }^{156}$

Furthermore, to characterize members in terrorist organizations as unlawful combatants and recognize them as subject to the laws of war could mean that, in certain instances, members of terrorist groups might be entitled to combatant and POW status. ${ }^{157}$ Such recognition would thus confer a degree of political legitimacy and respectability upon such groups that is neither warranted nor prudent.

153. U.S. CONST. art. I, $\S 9$, cl. 3.

154. The Nereide, 13 U.S. (9 Cranch) 388, 423 (1815) ("[T]he Court is bound by the law of nations which is part of the law of the land."); Harold Hongju Koh, Is International Law Really State Law?, 111 HARV. L. REV. 1824, 1824 (1998).

155. Fenrick, supra note 139, at 112.

156. Id.

157. See id. at 113 ("[I]f the [terrorist] organizations and their members accept and apply the laws of armed conflict, they cannot be referred to as 'terrorist organizations' in any legal sense. Compliance with the law brings respectability in its train.”). The Bush administration's decision not to classify officially the Guantanamo detainees as POWs has come under serious criticism as inconsistent with the Geneva Convention. See Katherine Q. Seelye, A P.O.W. Tangle: What the Law Says, N.Y. TimES, Jan. 29, 2002, at A14 (quoting one critic of the decision as saying "since the United States government engaged in armed conflict in Afghanistan-by bombing and undertaking other military operations-the Geneva Conventions clearly do apply to that conflict"). 
It has been suggested that the problems facing the president's Military Order could be remedied through legislation if Congress were to amend 10 U.S.C. $\S 821$ by authorizing commissions to prosecute not just violations of the laws of war but, also, violations of the broader laws of nations, which includes terrorism. ${ }^{158}$ Such a change would give the president a clear statutory basis to establish commissions for the prosecution of terrorists. ${ }^{159}$ As with the proposed change in customary international law, however, there are policy concerns that the use of military commissions might hinder the international campaign against terrorism. Spain, for example, has refused to extradite several suspected accomplices in the September 11 attacks to the United States because of fears that the suspected accomplices will face the death penalty. ${ }^{160}$ Proceeding with military commissions in which defendants can be sentenced by two-thirds of the appointed members ${ }^{161}$ is not likely to induce needed cooperation.

Trials in federal district courts or international war crimes tribunals would provide the most effective opportunities to convince the international community that the United States is proceeding fairly. With many Arab nations highly skeptical of the United States' military campaign, ${ }^{162}$ trials before military commissions are not the best means by which to make the case against terrorism, and those responsible for it, to the world community. In a period during which the international campaign against terrorism has achieved significant success, it would be a mistake to give the terrorists any such benefit.

\section{CONCLUSION}

The November 13 Military Order authorizing noncitizens suspected of complicity in the attacks of September 11, 2001 to be tried by specially convened military commissions was an extraordinary measure designed to deal with an extraordinary problem-a surprise attack by an independent enemy force that does not fit easily into existing legal categories of lawful or unlawful combatants.

\footnotetext{
158. Hearings, supra note 16 (testimony of Scott L. Silliman).

159. See id. (stating that such a change "would empower military commissions ... to prosecute acts of terrorism outside the context of a recognized state of armed conflict").

160. Frank Rich, Confessions of a Traitor, N.Y. TIMES, Dec. 8, 2001, at A23.

161. Department of Defense Military Commission Order, supra note 6, § 6(f).

162. Poll: Muslims Call U.S. 'Ruthless, Arrogant', CNN.com, at http://www.cnn.com/2002/ US/02/26/gallup.muslims/index.html (Feb. 26, 2002) (on file with the Duke Law Journal) (describing a poll in which a majority of people interviewed in nine Muslim countries were found to have unfavorable opinions of the United States and President Bush).
} 
Although, under Supreme Court precedent, the Order technically meets constitutional muster, it is inconsistent with existing international law, which holds that only state actors have legal personality that subjects them to the laws of war. While this inconsistency may change over time if new rules of customary international law develop, the Military Order, as currently written, retroactively applies what may be a developing customary rule in violation of the Ex Post Facto Clause of the Constitution. A new rule of international law, which recognizes that the jus belli can be applied to such entities as al Qaeda, may be applied to terrorists in the future if such a rule develops. There are, however, a host of serious policy considerations that must be considered aside from the expediency of applying such a rule as a means of prosecuting the war on terrorism. 